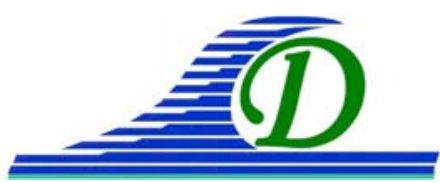

XIII ${ }^{\text {èmes }}$ Journées Nationales Génie Côtier - Génie Civil Dunkerque, 2-4 juillet 2014

DOI:10.5150/jngcgc.2014.030 (C) Editions Paralia CFL disponible en ligne - $h$ ttp://www.paralia.fr - available online

\title{
Multi-scale morphodynamics of sand barrier driven by monsoon/typhoon conditions
}

\author{
Lucie CAMPMAS $^{1,2}$, François SABATIER ${ }^{23}$, Samuel MEULE ${ }^{23}$, \\ Jiing-Yih LIOU ${ }^{4}$, Lise PETITJEAN ${ }^{1,2}$, Frédéric BOUTIN ${ }^{1}$, \\ Romain LEROUX-MALLOUF ${ }^{1}$, Damien SOUS ${ }^{2,5}$, Frédéric BOUCHETTE ${ }^{1,2}$
}

1. Géosciences-M, CNRS/Montpellier II University, 34095 Montpellier II, France.

2. GLADYS/SO-LTC, OSU OREME, CNRS/Montpellier II University, France.

3. Aix Marseille University, CNRS/CEREGE UMR 7330, BP 80, 13545 Aix, France.

4. National Cheng Kung University, No.1, University Road, Tainan City 701, Taïwan.

5. Toulon-Var Univ., MIO, 83957 La Garde, CNRS/INSU, MIO UMR7294, France.

Abstract: Island barriers are common features along the world coastlines. They have a crucial role in protecting inland and rich lagoonal ecosystems. Erosion and sand transfers on these island barriers during extreme events such as tropical storms or typhoons remain poorly investigated. This work focuses on a multi-scales analysis (season to decade) of the morphodynamics of Wan-Tzu-Liao sand barrier subjected to extreme waves and sea surges.

We combine topographic measurements of the emerged beach at seasonal scale between 2011 to 2012 and long-term (1993-2009) shoreline changes using aerial photographs and satellite images. At the seasonal scale, during monsoon, the sand was taken from the beach-front and transported seaward outside the study area. During typhoons season, 12 typhoons drove a beach recovery process resulting in a seaward shoreline shift. This annual behavior is discussed in term of roll-over process of the barrier. At the decadal scale, the shoreline changes evidence cross-shore processes in the north part of the barrier and longshore processes in the south. Although the chronic landward migration displays several stages, the strong losses of the barrier area occurs only since 2004 and call into question the general concept of conservation of mass during the roll-over of a barrier.

Keywords: Morphodynamic patterns, Monsoon/typhoons seasons, Shoreline changes

\section{Introduction}

Sand barriers are one of the most important system protecting inland during storms. Both short and long-term morphodynamics of sand barrier have been significantly studied in the literature (HOUSER et al., 2008; DONNELLY et al., 2004). However, only few studies combine the time scales and provide a multi-spatio-temporal analysis of a barrier dynamics (ROSATI et al., 2010; VAN-RIJN et al., 2011) especially when the system is forced by typhoons conditions. Because the short-term analysis is crucial to better understanding of long-term behaviors of the barrier, this study aims at 


\section{Thème 2 - Dynamique sédimentaire}

investigating the decadal evolution of the sand barrier of Wan-Tzu-Liao through a shortterm analysis of seasonal morphodynamic patterns. Supported by measures of the emerged beach in the central part of the barrier, the first part of this paper focus on one year (2011/2012) morphodynamics monitoring including a monsoon and a typhoons seasons. Supported by a dataset of historical shoreline locations since 1993, the second part of this paper describes the decadal morphologic changes of the barrier.

\section{Environmental settings}

The study area of Wan-Tzu-Liao sand barrier is located in the Cigu lagoon system southwestern Taïwan (figure 1a). CHEN \& KUO (2007) prove the eroding context of the region working on the Waisanding sand barrier located $40 \mathrm{~km}$ northern the study area. Due to coastal structures interrupting sand supply from local rivers, the Waisanding sand barrier area was eroded about 42\% (from 1986 to 1993) and the shoreline has been shifted $3.1 \mathrm{~km}$ landward between 1904 and 2003.

The Wan-Tzu-Liao sand barrier is $9 \mathrm{~km}$ long, width ranges between $100 \mathrm{~m}$ and $500 \mathrm{~m}$ and dune ranges between 2 to $5 \mathrm{~m}$ high above the mean sea level (MSL).

The peculiar study area monitored during one year is located in a middle part of the barrier. Area is $200 \mathrm{~m}$ long $\times 300 \mathrm{~m}$ width from the subtidal zone to the backbarrier with an homogeneous grain size ( $d_{50}$ about $200 \mu \mathrm{m}$ ). The dune is $3 \mathrm{~m}$ (above MSL) height covered by vegetation (figure $1 \mathrm{~b}$ ).

The southwestern coast of Taïwan is mainly forced by wind and wave forcings. Two major seasons occur: the winter season of monsoon and the summer season of typhoons. The monsoon drives local wave height $\left(H_{1 / 3}\right)$ ranges from 1 to $3 \mathrm{~m}$ (mean $\mathrm{Tp}=6.44 \mathrm{~s}$ ) with a southward alongshore drift. Summer is a mix between fair weather and highly energetic conditions during typhoons. Waves during fair weather are below $1 \mathrm{~m}$ with period between 4 to $7 \mathrm{~s}$ (LIAO et al., 2008) meanwhile six to eight typhoons (in average) are crossing or passing close to the island each year (ZHANG et al., 2013). Tides along the southwestern coasts of Taïwan are semi-diurnal and ranges about $2.68 \mathrm{~m}$ (CHEN \& KUO, 2007).

\section{Methodology}

Analysis from seasonal to annual time scales were supported by a robust one year monitoring from November 2011 to September 2012 and concerns only the peculiar study area in the middle part of the barrier. Twenty topographic surveys of the emerged beach were conduced from the subtidal zone to the back-barrier (MEULE et al., 2012). In this paper, we used surveys on 2011.10.21, 2012.05.03 and 2012.08.21 in order to focus on the seasonal morphologic changes. Using a kinematic RTK D-GPS (TRIMBLE R8), one topometric survey corresponds to the measure of the whole area (following a grid at a resolution of several points per $\mathrm{m}^{2}$ ) as well as a peculiar high resolution profile. 


\section{XIII ${ }^{\text {èmes }}$ Journées Nationales Génie Côtier - Génie Civil \\ Dunkerque, 2-4 juillet 2014}

Concomitantly, mesures provided by the Cigu offshore wave/wind buoy (1.5 km seaward the study area in $18 \mathrm{~m}$ of water depth (figure 1c)) and a pair of pressure sensors deployed vertically in the dune are processed to relate hydrodynamic forcings to morphological responses. Tide and inland wind conditions were respectively obtained from the northern Chun-Chin harbor gauge and the Weather Station (figure 1a).

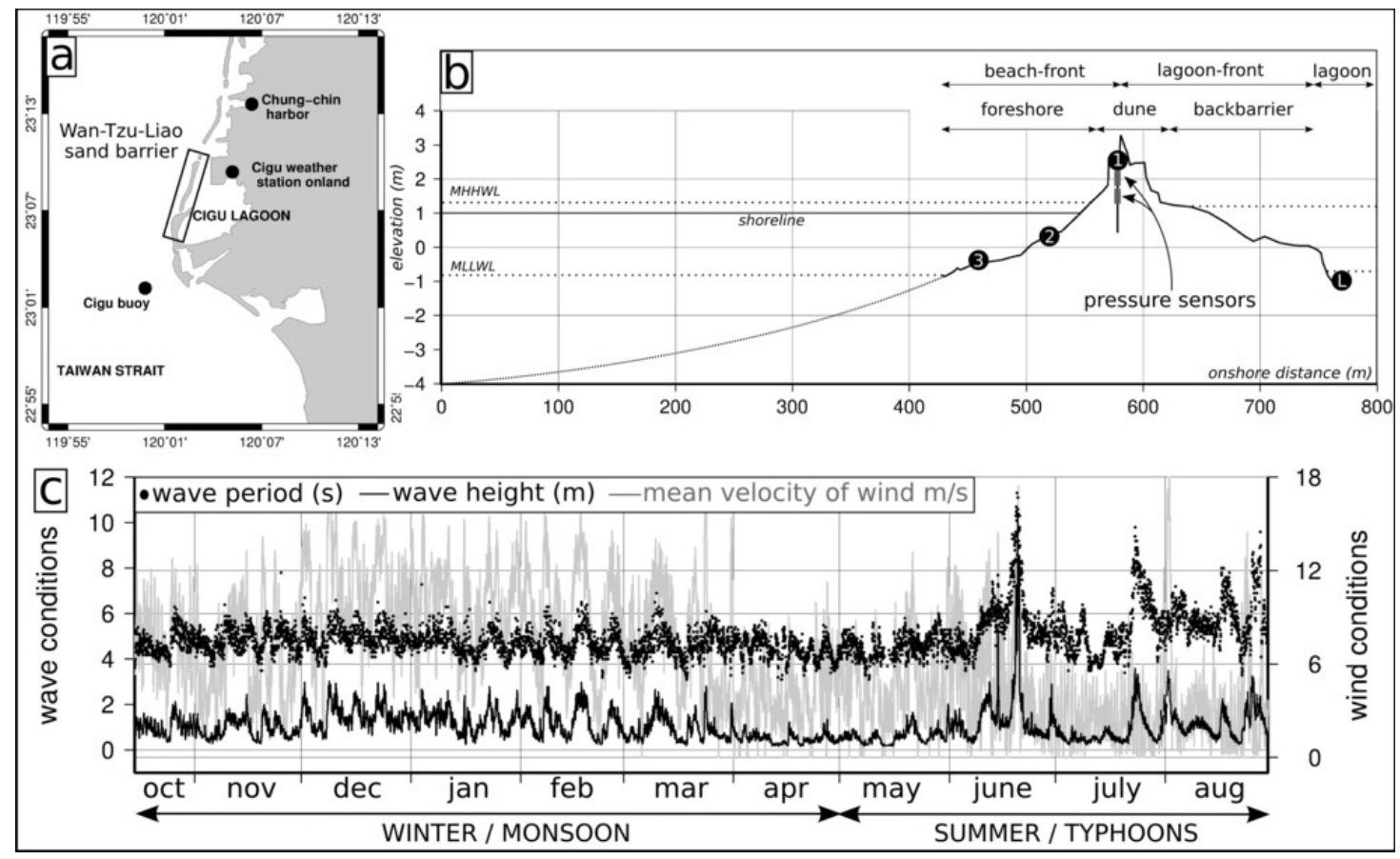

Figure 1. a) Study area of Wan-Tzu-Liao sand barrier. b) Crosshore profile of the study area monitored from 2011-2012 with typology used. Points number 1, 2 and 3 are reference points. c) Wave and wind conditions from 2011 to 2012. Waves are measured at Cigu buoy. Winds are measured at Cigu buoy until June 2012 and at the inland station from June to August 2012.

Regarding data processing, all analysis were performed using GMT Hawaii tools (WESSEL \& SMITH, 1998). Based on the topographic dataset, Digital Elevation Models (DEM) were built using AKIMA interpolation and differential of DEMs provide the sand volume changes maps (figure 2). We analysed sediment budgets of the beachfront (from subtidal zone to the dune crest) and the lagoon-front (from the dune crest to the lagoon). For more details, we analysed also the foreshore (up to the dune-foot), the dune area and the back-barrier (from dune-foot to the lagoon) (see figure 1b for typology used). In order to estimate the potentiel aeolian sediment transport from the beach to the backshore we used the empirical Bagnold equation (BAGNOLD, 1941). The isobath $\mathrm{Z}=1 \mathrm{~m}$ defines the shoreline location.

Analysis at the decadal time scale was supported by a dataset of shoreline position changes of the whole sand barrier measured in September/October of 1993, 1999, 2004 


\section{Thème 2 - Dynamique sédimentaire}

and 2009 years. Because of the lack of continuous morphological marker along the barrier, the shoreline locations were extracted from aerial photographs and satellite images at the boundary between wet and dry beach corresponding to the instantaneous run-up (BOAK \& TURNER, 2005). Indeed, the error results from the sum of the tide range, the run-up, the image resolution $(+/-20 \mathrm{~m})$ and the digitalization of the shoreline. Finally, the maximum error of shoreline location is about $88 \mathrm{~m}$. This value seems very high but is significantly lower than the shoreline movements (13\%). Consequently we assume order of magnitudes. Analysis of shoreline changes since 1993, were performed along 70 cross-shore transects separated from $100 \mathrm{~m}$ each others. Grey area on the figure 3a between transects 24 and 25 displays the peculiar study area monitoring from October 2011 to August 2012. Anthropic boundaries of the sand barrier (extreme north and south) have been excluded from the analysis.

\section{Results}

\subsection{Short term sand barrier dynamics driven by monsoon and typhoons conditions}

During the monsoon season (winter), bed elevation evidences erosion of the beach-front $\left(-6939 \mathrm{~m}^{3}\right)$ and sedimentation on the lagoon-front $\left(+1936 \mathrm{~m}^{3}\right)$ resulting in $4995 \mathrm{~m}^{3}$ of sand loss outside the studied zone (into the surf zone and/or the shoreface) and $28.9 \mathrm{~m}$ of shoreline landward shift. In details, erosion of the dune $\left(-2268 \mathrm{~m}^{3}\right)$ induces loss of the dune area and $14.6 \mathrm{~m}$ of dune-foot landward migration (figure 2a). In the dune, the watertable elevation do not reaches the pressure sensors and evidences the lack of overwash process along the season. Furthermore order of magnitude of the potential sand transport is about $0.23 \mathrm{~m}^{3} / \mathrm{h}$ during the monsoon season. Indeed, the dune-top and back-barrier nourishment $\left(+1684 \mathrm{~m}^{3}\right)$ is allocated to the aeolian sand transport driven by the strong and regular North wind of monsoon.

During the typhoons season (summer), sand balance displays an accretional regime $\left(+3556 \mathrm{~m}^{3}\right)$ and evidences sand input probably from the surf zone and/or the shoreface resulting in a shoreline seaward migration $(10.4 \mathrm{~m})$ and a dune-foot landward migration $(15.06 \mathrm{~m})$ (figure $2 \mathrm{~b})$. In details, the foreshore gains sediments $\left(+3174 \mathrm{~m}^{3}\right)$, the dune is eroded $\left(-578 \mathrm{~m}^{3}\right)$ and the back-barrier is nourished $\left(+960 \mathrm{~m}^{3}\right)$. Because rain prevents aeolian sand transport during typhoon events, the back-barrier nourishment is allocated to the cross-shore processes.

At annual scale, barrier records landward shifts of the shoreline $(18.5 \mathrm{~m})$ and the dunefoot (29.6 m without dune crest abrasion). The lagoon-front accumulation of $2998 \mathrm{~m}^{3}$ is allocated to a mix mechanisms between the aeolian transport during monsoon and overwash processes during typhoons. Considering the beach-front erosion of $4445 \mathrm{~m}^{3}$, the sediment balance suggests $1439 \mathrm{~m}^{3}$ of sand transfer outside the study area (figure 2c). This annual behavior is representative of roll-over barrier affected by overwash processes. 


\section{XIII ${ }^{\text {èmes }}$ Journées Nationales Génie Côtier - Génie Civil \\ Dunkerque, 2-4 juillet 2014}

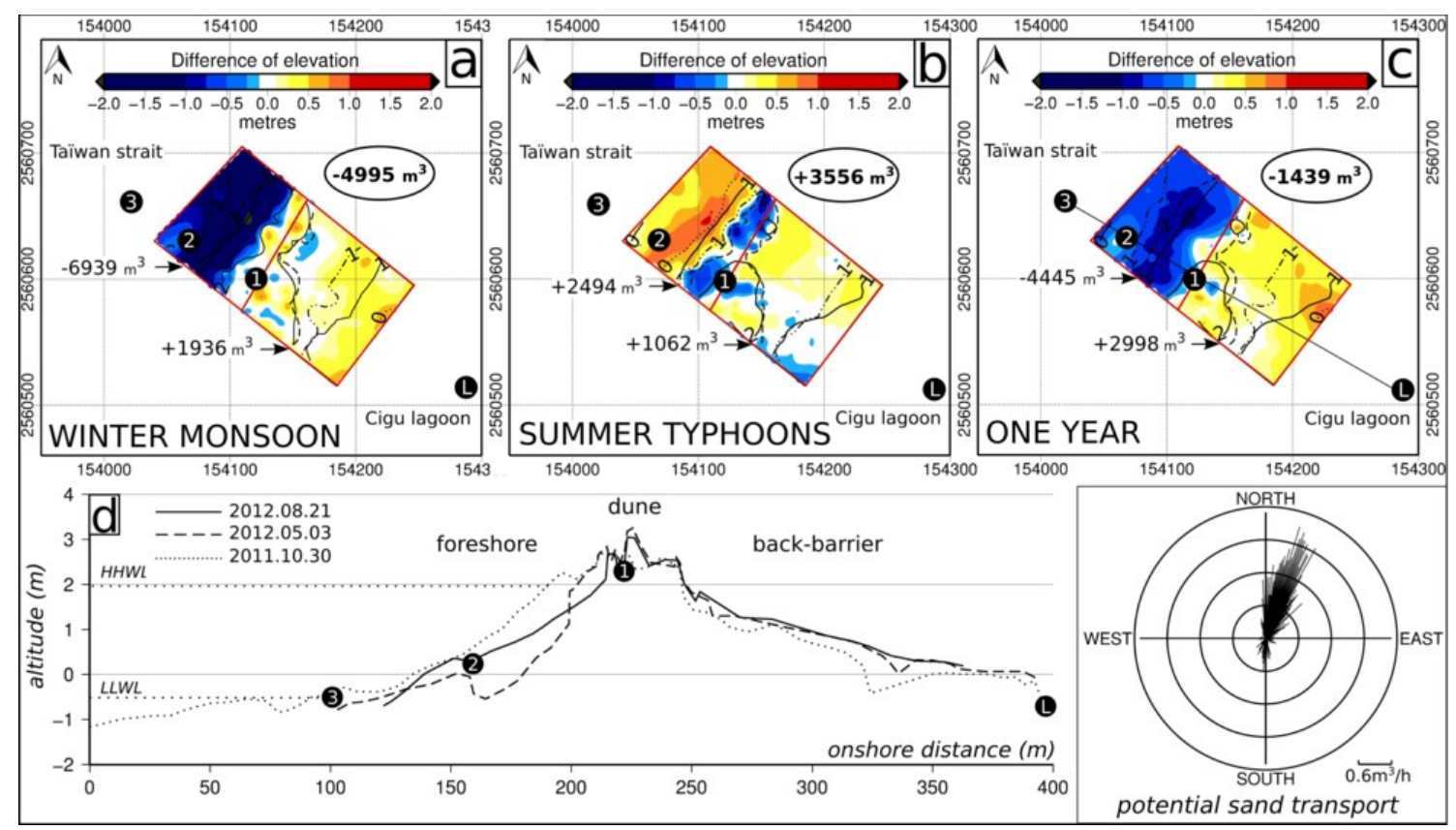

Figure 2. DEMs are used to build sand volume changes maps of a) winter season, $b$ ) summer season and c) the whole year 2011/2012. Solid and dashed lines display respectively isobaths at the youngest and oldest dates and the sand balances correspond to the respective red frames. d) Crosshore profile of the beach changes along seasons.

Black circles display reference points like describes above in figure $1 \mathrm{~b}$. Rose of the potential sand transport during monsoon 2011/2012.

\subsection{Long term sand barrier dynamics}

The sand barrier area remains stable from 1993 to 2004 (between 1905 and $1660 \mathrm{~km}^{2}$ ) but reduces significantly since 2004 and lost $1154 \mathrm{~km}^{2}$ (figure 3e). From 1993 to 2011, the shoreline changes analysis (figure 3 ) displays an eroding zone (transect 1 to 32) in the north part of the barrier and an accretional zone (transect 32 to 70) in the south part of the barrier.

In the eroding area, the shoreline shape changes from a lobed curve (1993) to a concave curve (since 2009) (figure 3a). Except in 1993, breaches and inlets are present in this area but appear and disappear at different locations without clear organization. The maximum crosshore retreat is about $937 \mathrm{~m}$ (at the transect $\mathrm{n}^{\circ} 17$ ) and the mean velocity of retreat is about $-41 \mathrm{~m} / \mathrm{yr}$ (figure $3 \mathrm{~b}$ ). In details, erosion of shoreline changes is about $48 \mathrm{~m} / \mathrm{yr}$ during two periods of 1993/1999 and 2004/2009 but only $25 \mathrm{~m} / \mathrm{yr}$ during the middle period of 1999/2004 (figure 3c and d).

The accretional zone displays an elongated spit. The southwesterly migration of the distal part of the spit is about $1184 \mathrm{~m}(+74 \mathrm{~m} / \mathrm{yr}$ in average) during the observed period. 


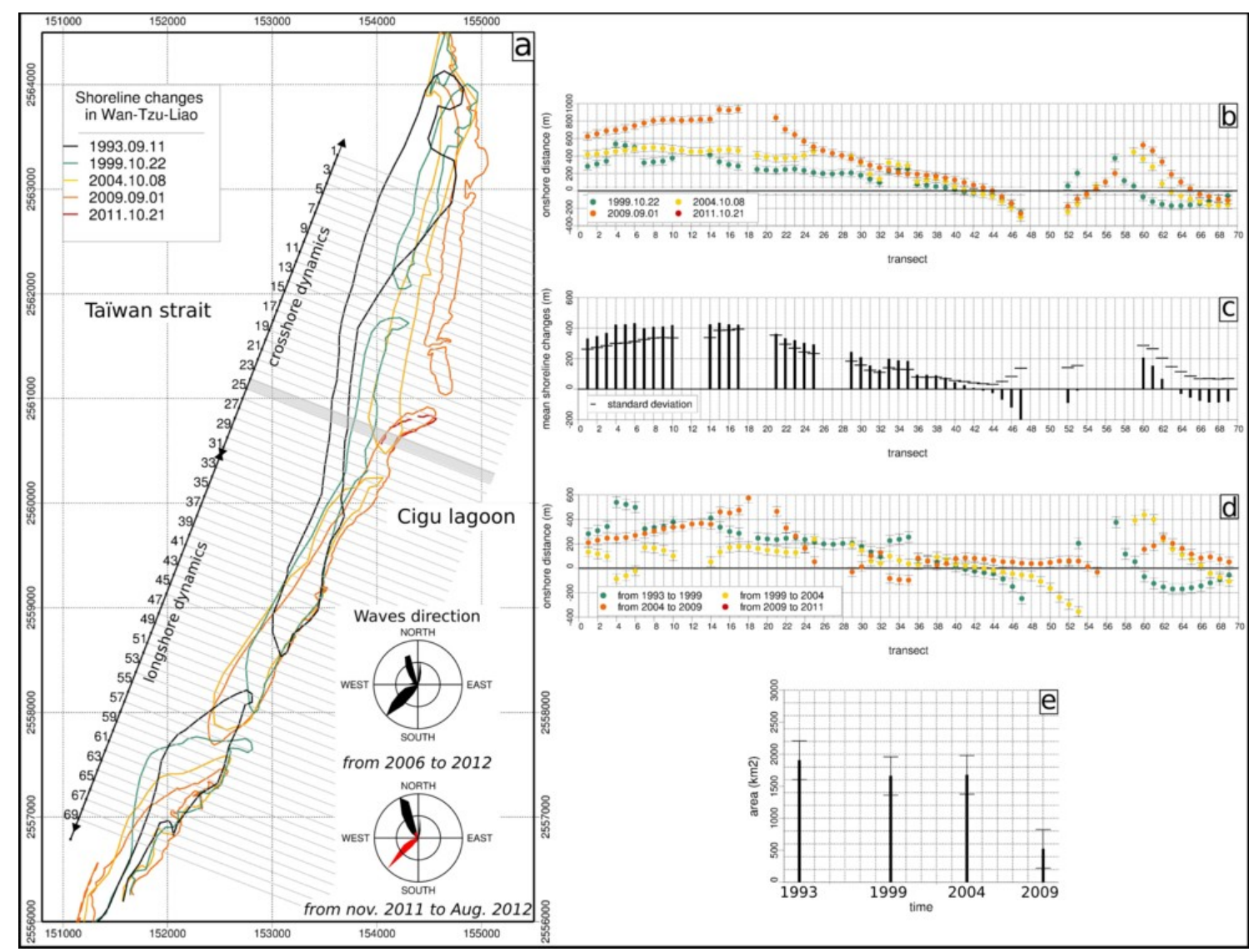

Figure 3. a) Shoreline changes in Wan-Tzu-Liao barrier from 1993 to 2009. Waves direction are measured at Cigu buoy. In the wave rose from 2011 to 2012, red and black colors display the typhoons and monsoon periods respectively. b) Changes of shoreline location compared to the shoreline location in 1993. c) Mean shoreline changes along the barrier. d) Shoreline changes between two dates. e) Barrier area changes.

\section{Discussion-conclusion}

The beach-front appears mainly controlled by cross-shore processes. In opposition to our expectation, typhoons season is not the major forcing agent of erosion but results in an accretion period (+3556 m3) with a foreshore nourishment and a shoreline seaward shift. The major agent of beach-front erosion are the moderate storm induced monsoon. The back-barrier dynamics results from a mix between longshore and crosshore processes. The back-barrier sand balance appears driven by a strong aeolian sand transport southward under north wind of monsoon and a sand transport landward driven by typhoons induced overwash.

Yearly, the major importance of typhoons on the roll-over processes of the barrier is to transport the sand landward from probably the surf zone and/or the shoreface to the foreshore and the back-barrier. The sand transported outside the study area probably in the surf zone and/or the shoreface during monsoon will be returned to the emerged 


\section{XIII ${ }^{\text {èmes }}$ Journées Nationales Génie Côtier - Génie Civil \\ Dunkerque, 2-4 juillet 2014}

beach driven by typhoons. The debate about the aim of large event (hurricane, typhoons) and classical storm to control the erosion of a barrier is still discussed in the literature, especially along the Est Atlantic coast of the US where conflicting papers exist (STONE et al., 2004).

The long-term shoreline changes suggest cross-shore sediments processes in the north part and the elongated spit in the south evidences a regular longshore transport of sediments (VAN RIJN, 1998) reshaping the barrier southward. Indeed, the south part of the barrier appears mainly controlled by longshore sand dynamics driven by northern wind of monsoon. However, the randomized distribution of the inlets in the north suggests a weaker longshore drift in this barrier part. Moreover, cross-shore processes are dominant during typhoons (low wave angle to the shoreline) performing a major control of the long term shoreline changes. But the annual $18.5 \mathrm{~m}$ of shoreline retreat between 2011 to 2012 suggests a decreasing of the shoreline landward migration. Although the landward shift of the barrier measured are lesser than changes observed on the Waisanding barrier northern (CHEN \& KUO, 2007), this shoreline retreat appears more rapid along Taïwan coasts than west Atlantic coasts (DOUGHTY et al., 2004; ROSATI et al., 2010).

Even if our analysis is based on shoreline changes and not topo-bathymetry, the strong reduction of the barrier area call into question the general concept of conservation of mass during the roll-over of a barrier (MASETTI et al., 2008; COWELL, 1995). There is no certitude that anthropic structures along coast interfere in the sand balance or if sand loss in the offshore is not present. For the future, this result and the extrapolation of the shoreline and area changes suggest that in the north zone, the barrier will disappear in 10 years. Nevertheless, the retreat of the eroding zone is not regular probably due to external agents like sand supply along coasts and coastal engineering. Consequently the forecasting is order of magnitudes but help coastal managers to anticipate coastal hazards.

\section{Acknowledgements}

We are grateful to the KUNSHEN-ANR project (SIMI6-2011) and the partnership in the framework of GLADYS (www.gladys-littoral.org) and SO LTC (www.soltc.org).

\section{References}

BAGNOLD, R.A. (1941). The physics of blown sand and desert dunes, 265 pp.

BOAK E.H., TURNER I.L. (2005). Shoreline definition and detection: A review. Journal of coastal Research, Vol. 21, pp 688-703. http://dx.doi.org/10.2112/03-0071.1

CHEN W.J., KUO C.T. (2007). Study on the evolution of sand barriers in Taiwan coast. River, Coastal and Estuarine Morphodynamics, Vol. 2, pp 85-91. 
COWELL P.J., ROY P.S., JONES R.A. (1995). Simulation of large-scale coastal change using a morphological behaviour model. Marine geology, Vol. 126, pp 45-61. http://dx.doi.org/10.1016/0025-3227(95)00065-7

DONNELLY J.P., BUTLER J., ROLL S., WENGREN M., ILI T.W. (2004). A backbarrier overwash recor of intense stroms from brigantine, New Jersey. Marine geology, Vol. 210, pp 107-121. http://dx.doi.org/10.1016/j.margeo.2004.05.005

DOUGHTY S., CLEARY W., Mc GINNIS W. (2004). The recent evolution of storminfluenced retrograding barriers in southeastern north Carolina, USA. Journal of Coastal Research, Vol. SI 39, pp 122-126.

HOUSER C., HAPKE C., HAMILTON S. (2008). Controls on coastal dune morphology, shoreline erosion and barrier island response to estreme storms. Geomorphology, Vol. 100, pp 223-240. http://dx.doi.org/10.1016/j.geomorph.2007.12.007

LIAO H.R., YU H.S., SU C.C. (2008). Morphology and sedimentation of sand bodies in the tidal shoelf sea of eastern Taiwan Strait. Marine Geology, Vol. 248, pp 161-178. http://dx.doi.org/10.1016/j.margeo.2007.10.013

MASETTI R., FAGHERAZZI S., MONTANARI A. (2008). Application of a barrier island translation model to the millennial-scale evolution of Sand Key, Florida. Continental Shelf Research, Vol. 28, pp 1116-1126. http://dx.doi.org/10.1016/j.csr.2008.02.021 MEULE S., CAMPMAS L., BOUCHETTE F., LIOU J.Y., SABATIER F., SOUS D., SYLVAIOS G., REY V., HWUNG H.H. (2012). Shoreline and upper beach dynamics under extreme events: the KUNSHEN experiment (Wan-tzu-liao beach barrier, Taiwan). XII $^{\text {èmes }}$ Journées Nationales Génie Côtier - Génie Civil, Cherbourg, France. http://dx.doi.org/10.5150/jngcgc.2012.034-M

ROSATI J., DEAN R., STONE G. (2010). A cross-shore model of barrier island migration over a compressible substrate. Marine Geology, Vol. 271, pp 1-16. http://dx.doi.org/10.1016/j.margeo.2010.01.005

STONE G., LIU B., PEPPER D.A., WANG P. (2004). The importance of extratropical and tropical cyclones on the short-term evolution of barrier islands along the northern Gulf of Mexico, USA. Marine Geology, Vol. 210, pp 63-78. http://dx.doi.org/10.1016/j.margeo.2004.05.021

VAN RIJN L.C., TONNON P.K., WALSTRA D.J.R. (2011). Numerical modelling of erosion and accretion of plane sloping beaches at different scales. Coastal Engineering, Vol. 58, pp 637-655. http://dx.doi.org/10.1016/i.coastaleng.2011.01.009

VAN RIJN L.C. (1998). Principles of coastal morphology. Aqua Publications, Amsterdam, The Netherlands, $730 \mathrm{p}$.

WESSEL P., SMITH W. (1998). New, improved version of the generic mapping tools released. American Geophysical Union, pp 79-579.

ZHANG W.-Z., HONG H.-S., YAN X.-H. (2013). Typhoons enhancing northward transport through the Taiwan Strait. Continental shelf research, Vol. 56, pp 13-25. http://dx.doi.org/10.1016/j.csr.2013.01.019 